\title{
Italy and Euroscepticism - political uncertainty gives way to temporary political relief
}

\author{
JESSICA QUIRK \\ jessicak.obrien86@gmail.com
}

\begin{abstract}
The 2018 elections in Italy produced an electoral outcome that caused much concern for the EU and often led to confrontation between Rome and Brussels, particularly over budget spending and migration policy. The coalition between 'populist' Five-Star Movement and the far-right League (Lega Nord) demonstrated a nationalist agenda and strong anti-EU sentiments. With over a year in power, the government saw the emergence of Matteo Salvini, whose dominance as the agenda setter continued to grow through his tough stance against migration. This was evidenced by the increased popularity and favourable results in the European Parliamentary elections of May 2019. The most recent of political crises, in Italy which saw Salviniundermine his government to trigger newnational elections to win the majority has backfired and left him sidelined with the creation of a new coalition between PD and the Five-Star Movement. This paper wishes to highlight the opportunity for the EU to show solidarity with Italy by supporting the new government on issues such as migration management and allowing flexibility on its budget. Taking this chance to improve Italian citizens' attitudes towards the union is imperative to reducing the risk of Salvini returning to power.
\end{abstract}

Keywords: Italy, EU, Italian politics, populism, Euroscepticism

\section{Introduction}

Government instability and upheaval triggered by Matteo Salvini causing a political crisis in August 2019, has provided the EU with a window of opportunity to address a rebellious and drifting Italy. One of the six founding members of the ECSC (European Coal and Steel Community) the precursor to the European Union, Italy has moved progressively from Europhile into a nation demonstrating anti-EU sentiments and a dissatisfaction with the rules and circumstances that come with being a member of not only the union but of the eurozone. The growing resentment in Italian citizens is a complex web of contributing factors that ultimately culminated in the election of Italy's first ever 'populist' government in 2018. The far right Lega, led by Matteo Salvini and 'anti-establishment' Five-Star Movement, led by Luigi Di Maio, were able to use the increasing discontent from issues such as economic decline, increasing poverty, the strain of mass immigration and years of political centre right domination, to capture the vote and form the $\mathrm{M}_{5} \mathrm{~S}$-Lega coalition. The government, seen to be led by Salvini, often clashed with the EU and other member states creating a level of discomfort and concern, with Italy openly rebuffing EU values by closing ports to migrant ships and setting a nationalist agenda involving plans of high public spending. The instability that has continued to dominate Italian politics, with 67 governments since the end of WW2, saw once again the breakdown of the elected coalition and 
ousting of Salvini into a place in opposition. The current and possibly temporary new coalition, formed by the democratic party (PD) and $\mathrm{M}_{5} \mathrm{~S}$ opens the door to the EU to show support and solidarity with Italy to halt the drift towards Euroscepticism and lessen the risk of Salvini returning to power in the near future.

\section{Political crisis leads to a cautious optimism in Brussels}

Crisis and relief are not often used in conjunction, however Italian government infighting and fragmentation that led Salvini to be sidelined and out of power, has allowed the EU a moment of reprieve and joy. The time Lega was in power saw numerous aggressive comments and manoeuvres towards Brussels which created ongoing headaches for both the previous leaders and the newly elected in 2019. Salvini denounced incoming Ursula von der Leyen for being old school and representing the politics that he wants to dismantle (Amante, 2019). An area of great contention was the budget with the Italian government submitting plans in 2019 to exceed spending limitations set out by EU regulations which were rejected by the EU (Bosotti, 2019). Tensions rose further with the issue of migration when Salvini drafted and championed the decree to toughen sanctions on humanitarian ships entering Italian waters bringing migrants rescued from the Mediterranean to Italy. The EU responded to the legislation stating that the Commission would need to analyse and verify whether it was compatible with European law (McGuinness, 2019). The combination of nationalist agenda with Salvini's strongman tendencies led Brussels to view the breakdown of the coalition and subsequent formation of new government as both favourable and positive. Salvini pulled his support for the $\mathrm{M}_{5} \mathrm{~S}$-Lega coalition once it became clear he had the majority of voter support and as tensions grew with his coalition partner. The power move was an attempt to force fresh election in which the Lega would likely have won a majority and formed a new coalition with the far-right Brothers of Italy, allowing Salvini to take the top position as Prime Minister. The move was described by current leader Giuseppe Conte as disloyal and showing Salvini putting himself before his country (Covelli \& Montalto Monella, 2019). The political gamble backfired and instead a coalition government made up of the pro-European democratic party and the Five-Star Movement emerged in September, led by Giuseppe Conte.

\section{Italy's new (fragile) coalition}

The current alliance between the PD and Five-Star is an opportunity for the EU and pro-European politicians to work together to address the growing dissatisfaction and the Eurosceptic drift that has emerged. The current coalition creates the environment for a more serene relationship between Brussels and Rome, however it would be remiss to ignore the potential temporary nature of this government. Having come into a position of leading Italy purely through an unlikely partnership to increase their own political power, both coalition members ought to be viewed as having more to gain together rather than apart despite many potential internal conflicts thus raising the question of how functionally can they govern? The democratic party occupies the centre - left space and is pro-EU which alleviates some of the tension with Brussels of keeping the Five-Star Party in power and is undoubtably a better alternative than a Lega led government. Having the PD in power also assists in mending relations with some other member states with whom Italy had bilateral conflicts under the previous administration, notably France (Euronews, 2019). Other member states and leaders have been reported to prefer the current government and interior minister Luciana 
Lamorgese to Salvini who was often accusatory (Reuters, 2019). The crucial budget for 2020 has been approved by the EU and is less confrontational in nature than that of the previous government (Il Globo, 2019). While the budget has no appetite for fiscal tightening or austerity and comes with a caution due to the risk of non-compliance with the Stability and Growth Pact, its approval brings with it a sense of relief and reduced tension. Opening the door to a greater level of communication and cooperation between Italy and the EU is the continued leadership of Prime Minister Giuseppe Conte. When addressing parliament at the formation of the new government he stated that it would be a more "mild mannered" government which is a direct comparison to Salvini's abrasive and confrontational style (Euronews, 2019). He has also stated "This is a time for new humanism" and to build "a more solid, more inclusive Europe" which again shows a willingness to align both policy and behaviour with the core values encouraged by those in Brussels and of membership within the union. The sentiment was put into action with the reopening of ports to NGOs ships carrying migrants. The less confrontational stance taken by Conte and his government has already seen a lift in mood between Rome and Brussels with former EU Commission president Junker (2019) demonstrating his content when congratulating Conte, "I am convinced Italy will be able to play an important role in addressing these truly European challenges, living up to its responsibility as a founding member of our Union” Junker J., 2019, twitter message dated 05/09/2019, viewed 27 March 2020. Conte and leader of the M5S, Di Maio both supported the nomination of incoming leader Ursula von der Leyen which again creates a more conducive environment for productive and successful policy creation and administration.

Both the EU and the current administration should use this time to work together to achieve a greater level of cooperation and management on key issues and to erode the popularity of Salvini. An area that has seen improvement under the coalition is migration, since Italy signed a preliminary agreement alongside interior ministers from France, Germany, Malta and Finland, to be presented to all member states, to distribute migrants saved from the Mediterranean across the EU which ultimately eases pressure and burden (Reuters, 2019). The relocation of migrants with the support of other member states will show a direct benefit of membership within the union, giving an opportunity for Italian citizens to lessen their distrust of Brussels. Effective migration management removes the weight of Salvini's xenophobic message. Since taking over the role of interior minister, Lamorgese has been able to shift the dialogue surrounding the issue of migration and has dismissed claims of Italy facing a migrant invasion (The Local Italy, 2019). This change of reporting and public perception about the impact of migrants on Italy, will force Salvini to move his focus and campaign policies to focus on the economy thereby making the management and avoidance of an Italian recession all the more important. Financial markets have settled under the current coalition with 10-year bond yields recovering to $1 \%$. This is positive news for the union but also for the people of Italy. A stable economy is essential for creating an environment with improving conditions. If Brussels can show public support to the Italian government by allowing flexibility on the budget, it could again detract from the appeal of Salvini to Italian citizens, slowing Eurosceptic views and could encourage a more pro-EU outlook for Five-Star politicians thus reducing the chance of a League return to power. 


\section{Italy and the EU - a brief history}

The Italian governments had been supporters of European integration and the formation of the union since the early 1950's however their idealistic intensions and their ability to implement what was required, rarely aligned (Daniels, 1998). Italy was a loud voice for the positive effects of a common market and pushed for the free circulation of goods, labour and capital in the lead up to the Treaty of Rome (Bindi,2011). The years following the treaty to 'create an ever closer union', saw numerous changes and reorganisation of cabinet in Italy, despite the dominance of the Christian Democrat party. The persistent instability further intensified with corruption scandals, and led to a nation whose attention was constantly disrupted by internal politics rather than a focus on European integration (Baratta, 2019). The formation of the single currency brought significant challenges given Italy's poor implementation history of the directives needed to complete a single European market. Adding to the pressure on Italy prior to adopting the Euro, was the severe speculation on the lira during the ratification process of the Maastricht Treaty, with the country needing to devalue their currency and raise interest rates. Italy showed a divergence from other member states such as Germany and the Netherlands on the compliance criteria for entry into European monetary union, preferring a dynamic rather than static view of assessment (Bindi 2011). This sentiment indicates a less than prepared government and economy or a lack of willingness to prepare and do what was required to meet entry targets. The Maastricht criteria was developed to ensure price stability could be maintained within the euro area even when new countries join. The convergence criteria have rules around inflation targets, public debt not exceeding $60 \%$ of the country's GDP, interest rate targets and the country having been a member of the economic monetary union (EMU) for two years without any unilateral devaluations of currency $(\mathrm{ECB}, 2020)$. This criterion was prohibitive for Italy with levels of debt in the 1990 s far too high to be considered, the country needed flexibility or would have to make drastic changes. It was the Italian people who would bear the brunt of efforts to meet the deadline for the launch of the single currency through measures such as a one off "Eurotax" introduced by Prime Minister Romano Prodi (Bindi, 2011). The Italian people accepted the tax in the hope for a better and more stable economic future as a member of the Eurozone. This expectation of what being a member of the EMU offers, is important to note, as it was the Italian citizens who were made to pay and promised a benefit of joining and the divergence between their hopes and dreams and the reality is an important contributor to the discontent of Italians today. Ultimately Italy was granted entry to the single currency at the time it was launched however the question of 'at what cost' has been asked many times.

\section{Italy's drift to Euroscepticism}

There have been a number of countries that have shown a shift towards Euroscepticism and growing support for political parties holding a nationalist or populist agenda, working against pan-European cooperation and instead pushing for the supranational powers of the EU to be returned to its member states (Janning, 2019). Italy is a country with some of the strongest anti-EU sentiments among its citizens, with more than $30 \%$ of survey respondents saying they would not know how to vote in a referendum in the case of their country's membership in the EU and 21 percent responding that membership in the union is a bad thing, second only behind the United Kingdom (Spring Eurobarometer, 2019). The move from Europhile to Eurosceptic is one that has occurred over several decades, with increasing momentum 
in recent years and is a trend that cannot be explained by a single cause but rather is multifactorial. Of the contributing elements, four are of particular influence - Italy's adherence to the Maastricht Treaty which has been discussed, the centre right domination in national politics, severe economic decline with rising poverty and the difficult management of immigration.

The mistrust and at times disgust shown towards the traditional political parties of Italy and the subsequent move towards support for those with an 'anti-establishment' message is the result of numerous events. The Tangentapoli scandal of the early $1990 \mathrm{~s}$ was the catalyst for the collapse of the previously dominant Christian Democratic Party who then scrambled to rebuild (Navarria, 2016). The next general election saw the arrival of Silvio Berlusconi as leader of Forza Italia who won the vote and secured a coalition with the Northern League and the fascist National Alliance. Despite the continued political instability and fragmentation, this domination of Berlusconi, a three-time Prime Minister saw an emergence of populism and strengthened Euroscepticism. During the period in which Berlusconi led Italy for almost a decade from 2000, the country's economy limped along with minimal growth and this made the blow of the global financial crisis all the more powerful (Hooper, 2011). Once again, the Italian people were left questioning those elected and feeling the unrelenting financial burden in their daily life rather than the economic prosperity they had been promised. A further push towards the populist parties was the impact of the migrant crisis starting in 2011, on a country already under pressure and feeling resources were stretched. Italy had suffered greatly following the sovereign debt crisis with the Monti government slashing public spending and raising taxes leading to a recession. The backlash from austerity measures and a technocratic government only intensified the discontent with the established parties of the Italian government.

Arguably the strongest factor behind discontent and disgruntlement among the people is the floundering of the Italian economy from which numerous issues stem, including but not limited to, poverty, high unemployment and a generation of Italians who will be worse off than their parents. The economic management and subsequent decline is a point that has continued to rear its head over time, fuelling the drift towards Euroscepticism. The ascent of Beppe Grillo, founder of the Five-Star Movement, gained his popularity with 'anti-politics' and heavy criticism of the Euro. His show that he took to the citizens of Italy spoke of a monster haunting Europe, the monster he described was the Euro. Grillo also stated that those who met with it often ended in misery (Barbati, 2014). This sentiment demonstrates the unease of being a Eurozone member and shows the temptation to blame 'an outsider' - the European Union - for the economic woes faced by Italy. This narrative is somewhat reduced but continued by Luigi Di Maio who has regularly criticized the banking union and has gone as far as to suggest the introduction in the treaties of "specific technical, economic and judicial procedures to allow member states to leave the monetary union or to remain outside it through a permanent opt-out." (Five Star manifesto as cited by Desideri 2018).

The increasing public debt and high unemployment particularly within the south and youth of Italy is proving to be a crushing weight on the spirit of the people. The effects of which are being felt nationally but are also far reaching with Italy demonstrating declining measures of structural and individual cohesion as measured by the European council of foreign relations between 2007 and 2017 (Janning, 2019). Within the nation is a growing sense of despair, fear, anger and helplessness as job security and certainty become less and less attainable. The second quarter of 2019 saw no growth, youth 
unemployment at $33 \%$, second highest in the eurozone and debt to GDP of $132 \%$ (The Economist, 2019). It is this picture that has led to a rise of populist party support within voters and is further intensified by the huge waves of migrants that have landed on Italian shores since the migration crisis beginning in 2015, whom are perceived to be taking resources and opportunities from a country who does not have enough nor in a position to offer support.

\section{Italian elections and the growing popularity of the Eurosceptics}

The national elections of 2018 saw the emergence of a populist government and an increase of voting share of the parties of the far right. The Five-Star Movement receiving $32.22 \%$ of the vote while Lega improved on their 2013 result by almost $14 \%$ to receive just under $18 \%$ of the vote (The Guardian, 2018). This growing su pport for Salvini and the Lega was continued in the European Parliamentary elections in May 2019 where the party improved their result (Euronews, 2019), making them the most popular party in Italy. The campaign of Lega and Salvini was of strong anti- migration policy and a sense of 'standing up' against Brussels, reflecting the anti-EU sentiments of the Italian people. Directly following the 2019 election results, Salvini stated "We're the first party in Italy, now Europe's going to change"thus showing a d esire and intent to force the agenda of not only himself but of Italy even if it means confrontation with the EU (The Local, 2019). Other League policies used in the campaign that show a divergence from the shared EU values include tax cuts with greater public spending while raising the possibility of a parallel currency, high fiscal spending and a foreign policy that encouraged closer relations with Russia (Scazzeri, 2019). Further reflecting the support towards the far right were the results of the party Brothers of Italy whose voter share also increased. While Salvini most likely would have softened his stance on particular issues, moving slightly into the centre-right space, there is enough reason for those in Brussels to be relieved he is currently in opposition, particularly with quotes including "The Euro is a failed project destined to end" and that former EU Commission President Jean Claude Junker and the EU "ruined Europe and our country" (Deutsche Welle, 2018).

\section{The alternative - The return of Salvini and a Lega led government}

Lega are currently the most popular party as shown in the recent European Parliamentary election and would likely hold a significant majority if there were to be a fresh vote (European Parliament, 2019). Recent regional results in Umbria demonstrate a consolidation of support for Salvini who backed the centre-right candidate, Donatella Tesei, who went on to win $57 \%$ of the vote. This marks the first time in more than 50 years that the centre-left have lost control of the region showing a clear shift in sentiment. The campaign of the region consisted of the usual antiimmigrant, anti-gay rhetoric, tax cuts and a revival of the Umbrian economy (Giuffrida, 2019). Salvini is undoubtably planning a return to power to push the country in a direction that aligns with his own agenda and is willing to wait for his chance to do so. Since his botched attempt at forcing new elections in August he has stated, "So we have to wait six months or a year to win? We are in no hurry" and "I will be even more determined, we are preparing to take this beautiful country in hand" (Salvini, 2019, twitter message dated 04/09/2019, viewed 26 March 2020).

With an authoritarian leadership style, having been described by critics as "fascist", compared to Benito Mussolini, holding nationalist, xenophobic, racist attitudes and 
an irresponsible desire for fiscal spending, a Salvini led government could have profound impacts on both Italy and the EU. There is the risk of Salvini calling on the citizens of the country to allow him "full powers" which could damage the democratic system underpinning the constitution (Scazzeri, 2019). A move in this direction would be cause for concern for the EU as democracy is a core value required by all its members. Another significant consideration is that confrontation with Brussels and an ambiguous view of the Euro is likely to rattle financial investors which makes the financing of Italy's crushing public debt more expensive. If this were to occur, then the likelihood of Italy leaving the Euro or attempting to establish a parallel currency becomes more likely. While the risks associated with a League led Italy have been averted with the current coalition, there is no room for complacency as the current government faces numerous challenges.

\section{Government fragility and chronic instability}

The next scheduled elections in Italy are in 2023 and it is evident that there is a myriad of factors that could prevent the current coalition from staying in power until that time. Italy has demonstrated a chronic instability of government since the end of WW2 with only one elected government serving a full term (Baratta, 2019). The possibility of a breakdown of the PD-Five-Star partnership has been discussed since its formation. The two parties are traditional opponents who have spent the past few years attacking one another and their policies and will likely clash on many issues (Scazzeri, 2019). With agreement unlikely in areas such as infrastructure and welfare, it leads observers and Italian citizens to question whether this coalition will be able to achieve what it has promised or anything at all (Giugliano, 2019). The mistrust of the two parties is so recent in history that former PD leader Matteo Renzi spoke of never forming a government with extremist parties as it was not an option for the Democrats, stating "There is no Five Star- led government that can win the confidence of the PD" (The Local, 2018). This sentiment has created further complications for the coalition with Renzi deciding to split from the PD party to create his own centrist party, his departure saw him take 26 seats, further weakening the government (Baratta, 2019). In order to address the Eurosceptic attitudes of citizens and to provide the relief and security that the people are craving, the coalition not only needs to find a way to work cohesively to prevent fragmentation but also to achieve what has been promised. Citizens of Italy have removed parties who cannot rekindle growth and support the economy in the past therefore it is likely this coalition will suffer the same fate if they are unable to improve conditions (Baccaro \& Lynch, 2019).

\section{Conclusion}

This paper has shown Italian citizens' attitudes and election results to be increasingly Eurosceptic and disgruntled with the current state of Italy within the union. The causes are varied and inter-related, the key of which is arguably the economy and economic situation being faced by the people. In order to address the Eurosceptic drift, a window of opportunity has been presented with the formation of a coalition between PD and Five-Star, to work more closely and offer support on migration management and leeway with the budget, showing solidarity with Italy to counter anti-EU sentiment. This opportunity faces many challenges including a fragile alliance of the current coalition and a determined and fierce opponent in Salvini who sees another way forward for Italy. 
Showing the value of membership within the union will go some way to addressing the anger and discontent of the Italian people but ultimately a full reversal of sentiment is unlikely in the short term as it will take a significant amount of time to address economic stagnation, unemployment and security. These issues will require sustained effective government policy and implementation to improve. It must also be acknowledged that this will not be the result of a political manoeuvre from a single

party or coalition. Currently there is the opportunity for an unlikely and awkward alliance to put forward a united government to work with the EU to change the opinions of Italians - the alternative is a Salvini led Italy which has the potential to create far more conflict and uncertainty.

\section{Bibliography}

Amante A., 2019, Italy's populist coalition clashes over EU Commission election. July 17, 2019, Reuters, https://www.reuters.com/article/us-italy-politics-europe/italyspopulist-coalition-clashes-over-eu-commission-election-idUSKCN1UC236, viewed 15 January, 2020.

Baratta G., 2019, Italy's Crisis: Weak Government and Political Fragmentation in the Second Republic. October 31, 2019, The McGill International Review, https://www.mironline.ca/italys-crisis-weak-government-and-political-fragmentation-in-thesecond-republic/, viewed 1 November 2019.

Barbati J.,2014, Italy turns from one of the most pro-EU countries, to the most Eurosceptic. February 21, 2014, Open Democracy, https://www.opendemocracy.net/en/can-europe-make-it/italy-is-quickly-turning-from-one-of-most-pro-eucountries-to-one-/, viewed 27 December 2019.

Bindi Federica M., 2011, Italy and the European Union. Brookings Institute Press.

Bosotti A., 2019, EU Crisis: Italy poised for new budget clash with Brussels as snap election looms. August 13, 2019, Express, https://www.express.co.uk/news/world/1165129/EU-news-Brussels-Italy-Matteo-Salvini-common-budgeteurozone-debt-snap-election-M5S-latest/amp, viewed 15 January 2020.

Covelli E, \& Montalto Monella L., 2019, Italy president holding talks to find new government after Conte quits. August 20, 2019, Euronews, https://www.euronews.com/2019/08/20/what-next-for-italy-as-resignation-of-pm-conte-looms, viewed 20 September 2019.

Daniels P., 1998, Italy in the European Union. Economic and Political Weekly, Vol. 33, No. 35 (Aug. 29 - Sep. 4, 1998), pp.107-112

Desideri E., 2018, Eurosceptic or Europhile? Shedding light on the Five Star Movement's stance towards the EU. April 5, 2018, Open Europe, https://openeurope.org.uk/today/blog/eurosceptic-or-europhile-shedding-light-onthe-five-star-movements-stance-towards-the-eu/, viewed 29 December 2019.

European Central Bank, 2020, Five things you need to know about the Maastricht Treaty. February 15, 2017, European Central Bank, https://www.ecb.europa.eu/explainers/tell-me-more/html/25 years maastricht.en.html, viewed 16 January 2020.

European Commission, 2019, Standard Eu robarometer 91, Spring 2019. European Union, https://ec.europa.eu/commfrontoffice/publicopinion/, viewed 26 October 2019. 
Giuffrida A., 2019, Salvini's coalition sweeps to power in Umbria elections. October 29, 2019. The Guardian, https://amp.theguardian.com/world/2019/oct/28/matteosalvinis-coalition-sweeps-to-power-in-umbria-elections, viewed 30 October 2019.

Giugliano F., 2019, Italy's Matteo Salvini Is Back With a Vengeance. October 29, 2019, Bloomberg, https://www.bloomberg.com/opinion/articles/2019-10-29/italys-matteo-salvini-is-back-with-a-vengeance, viewed 1 November 2019.

Hooper J., 2011, Silvio Berlusconi: a story of unfulfilled promises. November 13, 2011. The Guardian, http://theconversation.com/looking-back-at-1992-italyshorrible-year-66739, viewed 17 January 2020.

Il Globo, 2019, EU says it will approve Italy's 2020 budget, despite concerns. November 21, 2019, Il Globo, https://ilglobo.com.au/news/46063/eu-says-it-willapprove-italys-2020-budget-despite-concerns/\#, viewed 2 January, 2020.

Janning J., 2018, Crisis and Cohesion in the EU: A Ten-Year Review. February 5, 2018, European Council of Foreign Relations, https://www.ecfr.eu/publications/summary/crisis cohesion ten year review\#, viewed 30 September, 2019.

L’Espresso editorial team, 2019, Matteo Salvini vuole 'Pieni Poteri’. Come disse Benito Mussolini.August 9, 2019, L’Espresso, http://espresso.repubblica.it/palazzo/2019/08/og/news/salvini-vuole-pieni-poteri-come-disse-mussolini1.337718 ? refresh ce, viewed 3 January 2020.

Lucio and Lynch J., 2019, Expect the new Italian government to be as short-lived as the last one. Here's why. September 10, 2019, The Washington Post, https://www.washington-post.com/politics/2019/09/10/expect-new-italiangovernment-be-short-lived-last-one-heres-why/, viewed 6 January 2020.

Mammone,A., Italy is braced for a fascist-style fightback from a humiliated Salvini. September 17, 2019, The Independent, https://www.independent.co.uk/voices/italysalvini-coalition-5-star-fascist-far-right-immigration-a9109056.html, viewed 4 January 2020.

McGuinness R., 2019, EU Divided: Brussels sends Italy warning over migrant rescue law. August 7, 2019, Express, https://www.express.co.uk/news/world/1162936/EUnews-european-union-news-european-migrant-crisis-italy-matteo-salvini, viewed 14 January 2020.

Nadibaidze A., 2019, New Italian coalition government viewed positively in Brussels. August 29, 2019, https://openeurope.org.uk/impact/new-italian-coalitiongovernment-viewed-positively-in-brussels/, viewed 30 December 2019.

Navarria G., 2016, Looking back at 1992, Italy's horrible year. October 2, 2016, The Conversation, http://theconversation.com/looking-back-at-1992-italys-horribleyear-66739, viewed 17 January 2020.

Reuters, 2018, Italy's Matteo Salvini: EU has 'ruined our country'. October 5, 2018, Deutsche Welle, https://m.dw.com/en/italys-matteo-salvini-eu-has-ruined-ourcountry/a-45767182, viewed 2 November 2019.

Reuters, 2019, Italy Steps Up Placement of Migrants Around Europe. December 4, 2019, VOA News, https://www.voanews.com/europe/italy-steps-placementmigrants-around-europe?amp, viewed 4 January, 2020. 
Scazzieri, L., 2019, The EU should seize the chance to stop Italy's Eurosceptic drift. September 5, 2019, Centre for European Reform, https://www.cer.eu/sites/default/files/insight LS 5.9.19.pdf, viewed 10 October, 2019.

Scicluna, C., 2019, Five EU states agree migration deal, look for broader backing. September 23, 2019. Reuters, https://mobile.reuters.com/-article/amp/idUSKBN1W81W5, viewed 25 September 2019.

The European Parliament, 2019, European Election Results. European Parliament, https://europarl.europa.eu/election-results-2019/en/national-results/italy/20192024/, viewed 20 October 2019.

The Guardian, 2019, Italian elections 2018 - full results. March 6, 2018. The Guardian, https://www.theguardian.com/world/ng-interactive/2018/mar/05/italian-elections-2018-full-results-renzi-berlusconi, viewed 1 November 2019.

The Local, 2019, EU election results: Italy's League wins more than a third of vote. May 27, 2019, The Local, https://www.theloca; it/20190527/italy-europeanelection-results/amp, viewed 10 September 2019.

The Local, 2018, Matteo Renzi insists Italy's Democrats won't partner with Five Star Movement. March 12, 2018. The Local, https://www.thelocal.it/20180312/matteorenzi-democratic-party-five-star-movement-coalition/amp, viewed 27 March 2020.

The Local, 2019, 'We're not facing a migrant invasion', Italy's new interior minister. November 1, 2019. The Local, https://www.thelocal.it/20191101/no-migrantinvasion-says-italys-new-interior-minister/amp, viewed 4 January 2020.

Tidey, A., 2019, Italy's new government can get to work after getting senator's backing. September 10, 2019. Euronews, https://www.euronews.com/2019/09/10/italy-pm-says-new-government-will-clash-less-and-help-reform-the-eu, viewed 12 September 2019. 